\title{
STUDI POTENSI VARIABEL ANGIN ZONAL SEBAGAI PREDIKTOR UNTUK WILAYAH BENUA MARITIM (STUDI KASUS SUMATERA)
}

\author{
Agus Safril * dan Rista Hernandi Virgianto \\ Sekolah Tinggi Meteorologi Klimatologi dan Geofisika, Tangerang Selatan, Banten \\ *Email : Agus.safril@stmkg.ac.id
}

\begin{abstract}
ABSTRAK
Prediksi curah hujan menggunakan model global (Global Circulation Model) memiliki resolusi yang rendah sehingga tidak bisa memberikan informasi lokal. Untuk mendapatkan informasi skala lokal digunakan metode statistical downcsaling. Keandalan prediksi diperoleh dengan memilih variabel prediktor yang berhubungan erat dengan curah hujan. Pemilihan variabel prediktor dilakukan berdasarkan pertimbangan analisis spasial dan temporal di wilayah dengan pola hujan tahunan dan semi-tahunan. Analisis korelasi prediktor dan curah hujan dilakukan dengan metode SVD (Singular Value Decomposition). Hasil mode dominan koefisien ekspansi deret waktu dari hasil SVD dianalisis dengan transformasi wavelet. Hasil korelasi menunjukkan variabel angin zonal U850 terkait erat dengan curah hujan di Sumatera dengan korelasi 0,77 dan kesamaan keragamaan pasangan data (kovariansi) 92\%. Variabel angin U850 milibar dapat menangkap pola monsun (1 dan 0,5 tahunan) dan pola antar tahunan yaitu ENSO (El Nino Southern Ocillation) dengan periode 2, 4, dan 12 tahunan. Korelasi antara angin zonal (observasi) sekitar Sumatera dengan index Nino $3.4(>0,6)$. Kemampuan prediktor U850 mb lebih andal di bagian selatan Sumatera Utara dibandingkan selatan Sumatera. Secara umum predictor dapat digunakan untuk wilayah benua maritime yang berpola curah hujan tahunan dan semitahunan.
\end{abstract}

Kata kunci: Angin zonal, predictor umum, Singular Value Decomposition (SVD) dan statistical downscaling,

\begin{abstract}
Rainfall prediction using global model (Global Circulation Model) has a low resolution that can not provide local information. To obtain local-scale information, we need to apply a statistical downscaling method. Reliability of predictions is obtained by selecting predictor variables that are closely related to rainfall. The selection of predictor variables can be done based on spatial and temporal considerations that affecting predicted rainfall for annual and semi-annual cycle. The correlation analysis between predictor and rainfall were done by SVD (Singular Value Decomposition) method. The dominant mode of the expansion coefficient of the time series obtained from SVD is analyzed using the wavelet transform. The correlation results show that U850 zonal wind variable is closely related to rainfall in Sumatra with correlation of 0.77 and $92 \%$ of covariance. The U850 millibar wind variable can capture monsoon patterns ( 1 and 0.5 year) and the interannual pattern is ENSO (El Nino Southern Ocillation) with periods of 2, 4, and 12 years. Correlation between zonal wind (observation) around Sumatra with Nino index. $3.4(>0.6)$. The U850 mb predictor capability is more reliable in the southern part of North Sumatra compared to southern Sumatra. In general, predictors can be used for the annual and semi-annual of rainfall in maritime region.
\end{abstract}

Keywords: Zonal Wind, Singular Value Decomposition (SVD), Statistical Downscaling

\section{PENDAHULUAN}

Indonesia merupakan negara agraris, sebagian besar penduduknya hidup dari bercocok tanam. Petani membutuhkan informasi curah hujan untuk penentuan jadwal tanam di bidang pertanian terutama informasi untuk waktu ke depan. Untuk kebutuhan penanaman padi diperlukan prediksi dengan jangka waktu musiman. Prediksi hujan musiman adalah prediksi hujan jangka panjang (Long-range Forecasts) yang memiliki jangka waktu 30 hari - 2 tahun (WMO, 2001). Informasi prediksi hujan tersebut digunakan untuk strategi budidaya di bidang pertanian (Boer dkk., 2007). 
Berbagai metode prediksi dikembangkan untuk mendapatkan keandalan prediksi sehingga pengguna percaya terhadap informasi. Semakin akurat hasil prediksi semakin tinggi tingkat kepercayaan pengguna untuk memanfaatkan informasi prediksi tersebut.

Metode prediksi yang digunakan antara lain model prediksi dengan statisitik dan dinamis. Model prediksi menggunakan dinamis dalam skala global (Global Circulation Model) memiliki kekurangan resolusi yang rendah. Untuk mengatasi hal tersebut agar diperoleh informasi yang lebih rinci (resolusi yang lebih tinggi) maka digunakan model output statistic (MOS) atau statistical downscaling.

Keandalan suatu model prediksi statistical downscaling tersebut ditentukan oleh ketepatan dalam memilih variabel prediktor (Mason dan Baddour, dalam Troccoli dkk., 2008). Selain itu keandalan ditentukan oleh variabel prediktor, dan pemilihan kotak grid predictor (grid box dalam peta), dan model regresi yang dipilih (Wilby dkk., 2004).

Agar didapatkan variabel terbaik maka variable yang diperlukan adalah variabel yang mampu menangkap pola anomali curah hujan yang disebabkan oleh fenomena iklim seperti monsun, ENSO (El Nino Southern Oscillation. Kotak grid yang dipilih pada varibel prediktor tersebut yang terkait secara fisis dengan curah hujan yang diprediksi (Tatli dkk., 2004; Kang dkk. 2007, dan Juneng dkk., 2010). Penelitian terdahulu di wilayah tropis prediktor dominan di Malaysia (Juneng dkk., 2010) menggunakan metode optimal windows (kotak grid). Optimal window dilakukan dengan mencari kotak grid yang dengan cara menggeser kotak grid sehingga diperoleh korelasi yang paling tinggi antara prediktor dan prediktan (curah hujan).

Dalam penelitian Juneng dkk (2010) tentang prediksi curah hujan di wilayah Semenanjung
Malaysia dengan statistical downscaling diperoleh sejumlah prediktor (multivariabel). Dalam prediksi curah hujan oleh prakirawan cuaca untuk prediksi prediksi curah hujan dengan prediktor tunggal lebih mudah dalam operasional. Berdasarkan kondisi tersebut diperlukan. penyederhanaan penggunaan variabel prediktor. Dalam penelitian ini dilakukan studi fisis potensi 2 U850 secara spasial dan temporal. Dari studi studi ini didapatkan prediktor yang secara umum dapat diterapkan di wilayah benua maritim (berpola hujan tahunan dan semi tahunan).

\section{DATA DAN METODE \\ 1.1 Data}

\subsubsection{Data Hujan Observasi}

Data yang digunakan merupakan data curah hujan harian yang diolah menjadi curah hujan bulanan tahun 1981-2005 dari stasiun pengamat cuaca Badan Meteorologi, Klimatologi, dan Geofisika wilayah Sumatera (Gambar 1). Pulau Sumatra dipilih sebagai studi kasus untuk mewakili Kepulauan Indonesia mempunyai pola hujan tahunan (A) dan pola hujan semi tahunan (B) (Aldrian dan Susanto, 2003). Untuk wilayah Sumatra bagian utara diwakili 10 stasiun hujan (Sabang, Banda Aceh, Lhokseumawe, Meulaboh, Polonia (Medan), Sibolga, Binaka, Padang, Rengat, dan Pakanbaru) yang mewakili pola hujan semi tahunan dengan dua kali puncak hujan maksimum (pola semi tahunan). Wilayah selatan Sumatera meliputi enam stasiun hujan (Jambi, Muara Bungo, Palembang, Bengkulu, Way Kanan, dan Branti) yang mewakili pola hujan tahunan dengan satu kali puncak hujan maksimum (pola tahunan). Penelitian lain, wilayah kepulauan Indonesia terdiri dari curah hujan siklus musiman dan siklus semitahunan (Chang dkk., 2005). Untuk Pulau Sumatera, wilayah dengan siklus hujan semitahunan (dengan dua puncak hujan) di wilayah Sumatra bagian utara. Sedangkan wilayah selatan Sumatera mempunyai siklus hujan tahunan 


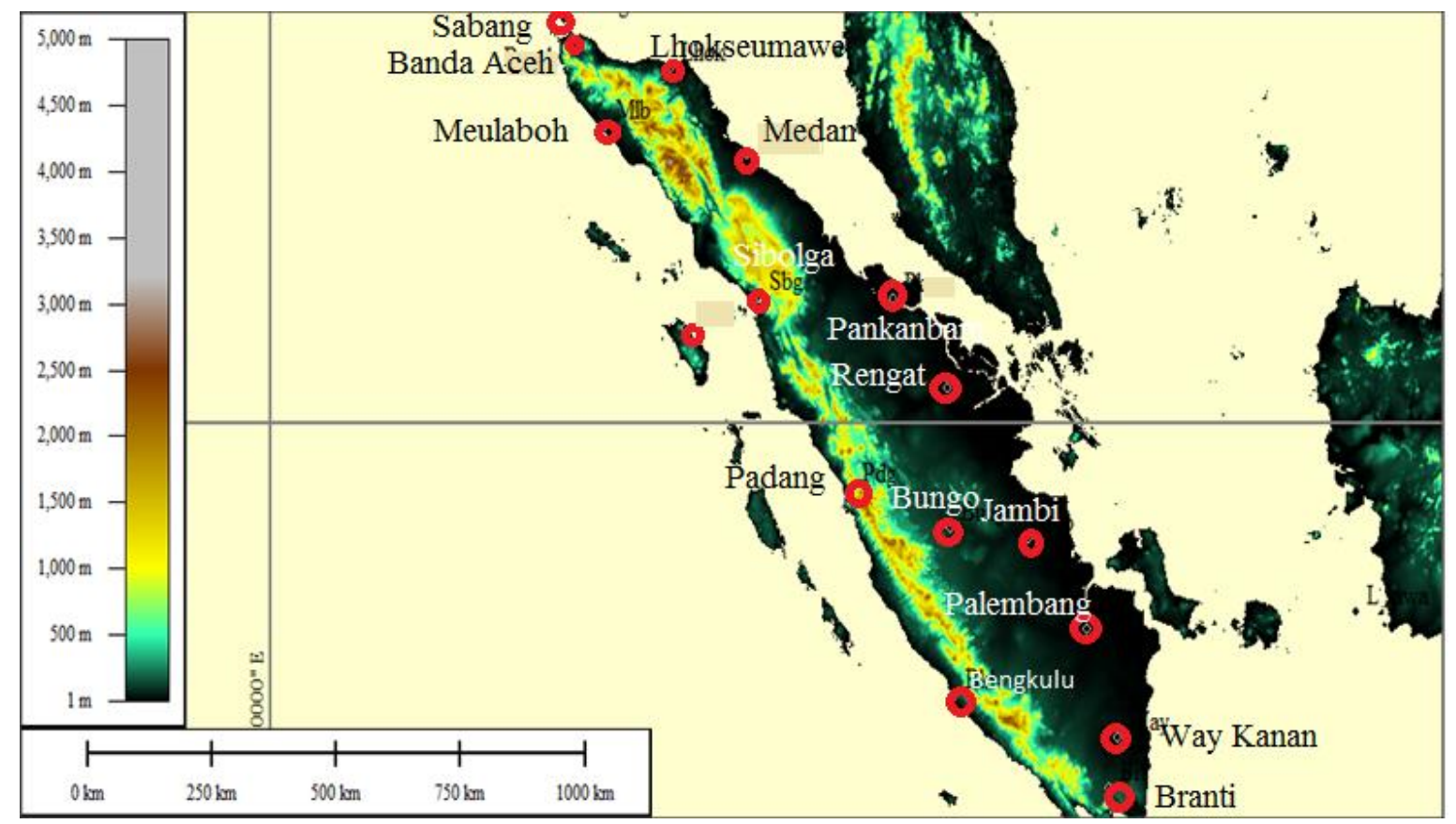

Gambar 1. Stasiun pengamatan curah hujan (Digital Elevation Model DEM, USGS. USA)

Pemilihan stasiun hujan juga berdasarkan geografis yang mempunyai karakteristik curah hujan tersendiri di pulau besar yang terdiri dari dataran tinggi dan rendah dan pulau kecil, Wilayah Sumatra terdiri barisan pegunungan (Bukit Barisan) di pantai barat dan dataran rendah di pantai timur. Stasiun yang mewakili pantai barat (dataran tinggi) adalah stasiun Meulaboh, Sibolga, Padang, dan Bengkulu. Pantai timur merupakan dataran rendah yang diwakili oleh stasiun Banda Aceh, Lhokseumawe, Polonia, Pakanbaru, Rengat, Jambi, Muara Bungo, Palembang, Way Kanan, dan Branti. Sedangkan stasiun untuk mewakili pulau kecil di sekitar pulau Sumatra adalah stasiun Sabang dan Binaka.

\subsubsection{Data Variabel Prediktor, Hujan model, dan Reanalisis}

Data variabel prediktor yang digunakan dalam penelitian terdiri angin zonal paras 850 milibar lead time (satu bulan ke depan). Dasar pemilihan variabel U850 karena secara fisis merupakan lapisan bebas hambatan dan tinggi dasar awan terbentuk. Variabel ini model global dari Central Weather Beurau (CWB) China Taipei dengan 10 anggota ansambel, seperti terlihat pada Tabel 2.1. Data diperoleh dari APEC Climate Center (APCC) Korea Selatan.

Tabel 1. Deskripsi Model Global operasional CWB (Sumber : APCC)

\begin{tabular}{|l|l|l|}
\hline No & Deskripsi & Lembaga \\
\hline
\end{tabular}

\begin{tabular}{|l|l|l|}
\hline 1 & $\begin{array}{l}\text { Model Sirkulasi } \\
\text { Global (Global } \\
\text { Circulation Model) }\end{array}$ & $\begin{array}{l}\text { Central Weather } \\
\text { Bureau China Taipei } \\
\text { (CWB) }\end{array}$ \\
\hline 2 & Resolusi & T42 \\
\hline 3 & Jumlah Ansambel & 10 anggota \\
\hline
\end{tabular}

Pemilihan variabel predikor dengan menggunakan 10 anggota ansambel ini karena prediksi cuaca/iklim tidak dapat mencegah beberapa ketidakpastian. Model ensemble ini menggunakan beberapa syarat awal (inital condition).

Variabel prediktor diperoleh dengan merataratakan anggota ansambel hasil keluaran model sirkulasi umum (rata-rata ansambel). Anggota ansambel prediksi numerik adalah hasil prediksi deterministik dari model sirkulasi umum dengan syarat awal (initial condition) yang berbeda. Hasil rata-rata ansambel digunakan sebagai masukan untuk prediksi dengan bantuan statistik (statistical downscaling). Data variabel prediktor diperoleh dari model sirkulasi umum (Global Circulation Model) dengan resolusi $2,5^{\circ}\left(1^{\circ}\right.$ $=111 \mathrm{~km}$ ).

Untuk keperluan interprestasi fisis digunakan data observasi reanalisis keluaran dari NCEP (National Centers for Evironmental Prediction) dengan resolusi $2,5^{\circ}$. Data yang digunakan meliputi data bulanan angin zonal pada lapisan $850 \mathrm{mb}$ (U850), angin vektor, dan air mampu curah (precipitable 
water) (tahun 1981-2005). Pengolahan datan menggunakan perangkat lunak Ferret yang dikeluarkan oleh NOAA (National Oceanic and Atmospheric Administration). Sumber data reanalisis yang digunakan berasal dari NOAA (USA) dengan

alamat sebagai berikut : http://www.esrl.noaa.gov/psd/data/reanalysis/r eanalysis.shtml.

\subsection{Metode}

Analisis pemilihan variabel prediktor dilakukan dengan langkah:

1) Pemilihan kotak grid berdasarkan penelitian terdahulu mengenai pengaruh variabilitas iklim di Sumatra (ENSO) dan monsun berdasarkan hasil kajian studi pustaka.

2) Analisis korelasi spasial antara prediktor dan curah hujan menggunakan SVD (Singular Value Decomposition) secara spasial untuk mendapat variabel terbaik.

3) Analisis daya wavelet pada koefisien ekspansi (deret waktu) hasil SVD variabel prediktor dan curah hujan dan analisis fisis. Analisis ini dilakukan untuk mendapatkan kemampuan variabel prediktor mampu mengikuti variabilitas curah hujan di daerah prediksi (pola hujan tahunan, semitahunan) akibat pengaruh ENSO.

\subsubsection{Analisis Korelasi Spasial antara Variabel Prediktor dan Curah Hujan}

Tujuan analisis ini adalah untuk mendapatkan kekuatan hubungan antara variabel prediktor dengan curah hujan observasi di daerah prediksi berdasarkan deret waktu. Analisis korelasi dilakukan antara deret waktu variabel prediktor dengan deret waktu curah hujan observasi yang menggunakan metode SVD (Singular Value Decomposition) (Bjornson dan Venegas, 1997). Korelasi yang dilakukan antara kedua variabel tersebut dengan koefisien ekspansi dari mode yang paling dominan.

Metode SVD merupakan metode yang digunakan untuk mengidentifikasi pasangan bidang (matriks) yang bervariasi terhadap ruang dan waktu. Diasumsikan beberapa variabel di lokasi $x_{1}, x_{2}, \ldots . . x_{\mathrm{p}}$ yang terjadi waktu $t_{1}, t_{2} \ldots \ldots t_{\mathrm{n}}$, untuk tiap waktu adalah $t_{\mathrm{j}}$ $(\mathrm{j}=1, \ldots \ldots . . n)$ dari pengamatan $\mathrm{x}_{i}(\mathrm{i}=1 \ldots . \mathrm{p})$ sebagai dalam bentuk sebuah peta spasial

Sebelum metode menggunakan SVD untuk menentukan korelasi dua variabel, data terlebih dahulu dinormalisasi pada variabel bebas. Tiap pasang bidang variabel tersebut menjelaskan suatu pecahan (fraksi) kovariansi. Analisis korelasi dilakukan pada koefisien ekspansi mode paling dominan pada variabel bebas dan curah hujan. Nilai korelasi dalam rentang antara 0 (lemah) sampai dengan 1 (kuat). Persamaan untuk mendapatkan koefisien ekspansi sebagai berikut :

Variabel bebas dan bergantung merupakan sepasang matriks yang terdiri dari 2 matriks (X dan $\mathbf{Y}$ ). Matriks $\mathbf{X}$ merupakan variabel bebas (X) dan matriks $\mathbf{Y}$ adalah variabel curah hujan observasi dengan periode waktu yang sama. Matriks kovarian dibentuk dengan persamaan $\left(\mathbf{X}^{\mathbf{T}}\right.$ dapat dihitung apabila mempunyai jumlah baris yang sama dengan $\mathbf{Y}$ sebagai deret waktu).

$\mathbf{C}=\mathbf{X}^{\mathbf{T}} \mathbf{Y}$

Selanjutnya dibentuk matriks kovarians C selanjutnya dihitung nilai Singular Value Decomposition (SVD) dan diperoleh matriks $\mathbf{U}, \mathbf{V}$ dan matriks diagonal $\mathbf{L}$ sehingga diperoleh:

$$
\mathbf{C}=\mathbf{U} \mathbf{L} \mathbf{V}^{\mathbf{T}}
$$

dari vektor singular $\mathbf{X}$ merupakan kolomkolom pada $\mathbf{U}$ dan vektor singular dari $\mathbf{Y}$ adalah kolom-kolom dari V. Vektor singular adalah matriks bujur sangkar dengan determinan 0. Kolom $\mathbf{U}$ sebagai pola kiri dan kolom $\mathbf{V}$ merupakan pola kanan sedangkan C adalah matriks kovarians. Koefisien ekspansi (deret waktu) yang dihasilkan dari SVD dalam bentuk mode menyatakan osilasi variabilitas variabel dalam bentuk deret waktu.

selanjutnya matriks $\mathbf{X}$ dihitung,

$$
\mathbf{A}=\mathbf{X U}
$$


matriks $\mathbf{Y}$ dihitung :

$\mathbf{B}=\mathbf{Y} \mathbf{V}$

Hasil korelasi antara antara variabel bebas(A) dan curah hujan (B) secara spasial digunakan untuk menentukan kekuatan relasi kedua variabel tersebut (variabel bebas dan curah hujan).
Selanjutnya dilakukan daya wavelet untuk mengetahui kemampuan variabel prediktor dalam menangkap pola monsun, dan ENSO. Gustari (2009) berdasarkan metode yang yang dilakukan oleh Torrence dan Compo (1998) melihat frekuensi curah hujan berdasarkan domain waktu dan frekuensi menggunakan CWT (Cross Wavelet Transform).

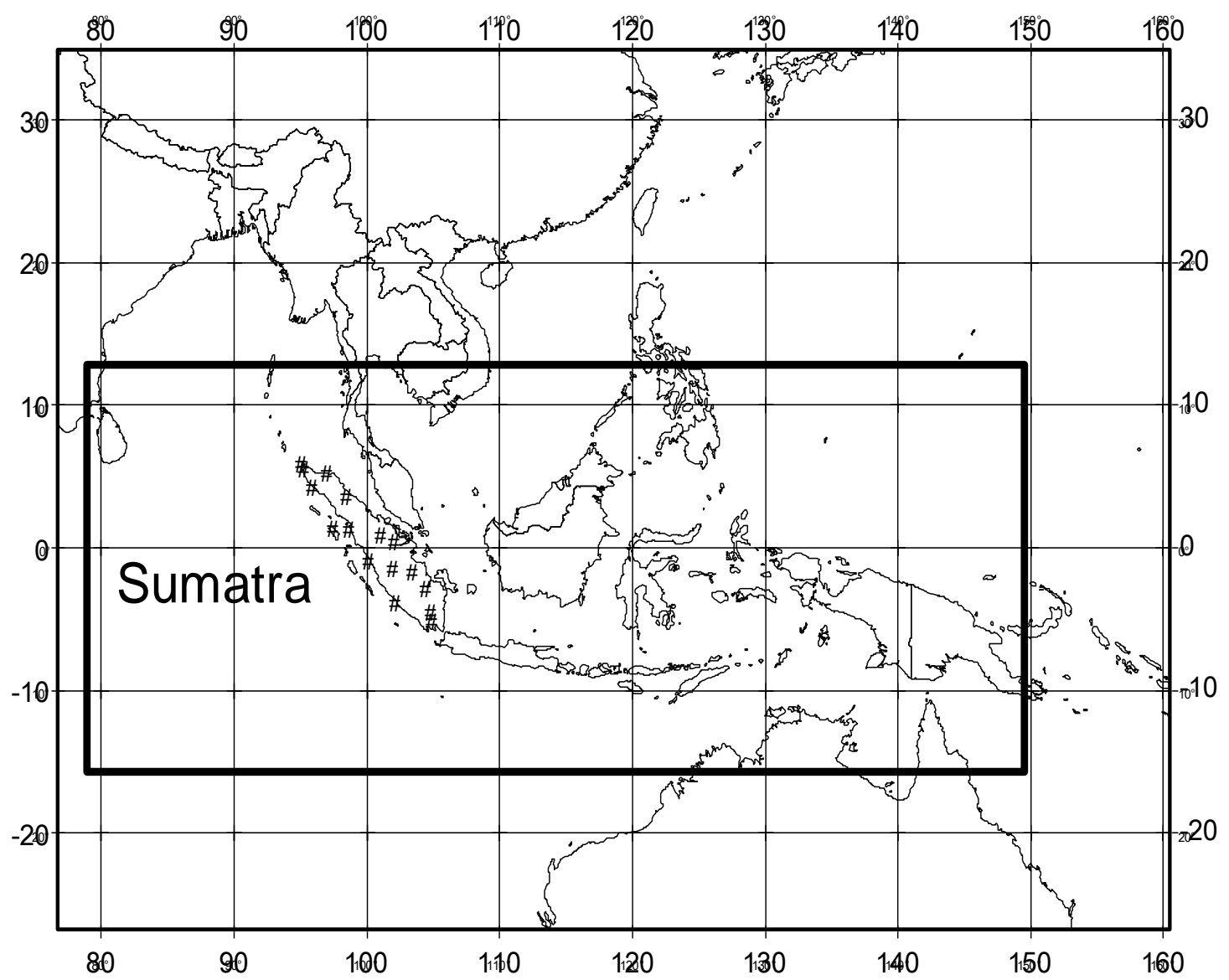

1. Gambar 2 . Kotak Grid (grid box) /Kotak grid prediktor benua maritim pada koordinat $80^{\circ} \mathrm{BT}-150^{\circ}$ $\mathrm{BT}, 12,5^{\circ} \mathrm{LU}^{\circ}-12,5^{\circ} \mathrm{LS}$

2. 
$\mathrm{W}_{\mathrm{dw}}(\mathrm{s}, \mathrm{t})=\left(\mathrm{x}(\mathrm{t}) * \psi_{\mathrm{s}}(\mathrm{t})\right)$

Dengan t adalah waktu, $\psi_{\mathrm{s}}$ dalam skala s yang terkait dengan periode wavelet. $\left|\mathrm{W}_{\mathrm{dw}}\right|^{2}$ sebagai daya wavelet.

\subsubsection{Pemilihan Kotak Grid Berdasarkan Pengaruh Monsun, IOD dan ENSO}

Pemilihan kotak grid berdasarkan kotak grid prediktor yang secara fisis mempengaruhi curah hujan di wilayah prediksi. Kotak grid prediktor yang mempengaruhi karakteristik curah hujan Sumatra (wilayah benua maritim) dipilih kotak grid wilayah Laut Cina Selatan, Pasifik Barat dan Australia bagian utara, dan Lautan Hindia. Hal ini berdasarkan interprestasi dari pengaruh kajian sebelumnya tentang pengaruh ENSO terhadap wilayah Sumatra yang dilakukan oleh Chang, dkk., (2004).

Variabilitas curah hujan diwilayah bagian utara Sumatra dipengaruhi fenomena global yang disebabkan oleh pengaruh fenomena ENSO secara tidak konsisten di wilayah tersebut (Prabowo, 2011). Penelitian lain menunjukkan pada Saat ENSO positif curah hujan di wilayah Sumatra bagian utara pada bulan Juni- Juli- Agustus bertambah (Harijono, 2008). Hal ini disebabkan terjadi anomali pola angin, pada saat ENSO aktif yang membawa pengaruh ke wilayah Sumatra bagian utara. Pada tahun-tahun El Niño pada fase hangat di Nino 3 El Nino (1983, 1987, 1982, 1998) kondisi kering.

Gambar 3. Rata-rata komposit vektor angin tahun 1981-2005, sumber data : http://www.esrl.noaa.gov/psd/cgi-bin/data/composites/printpage.pl
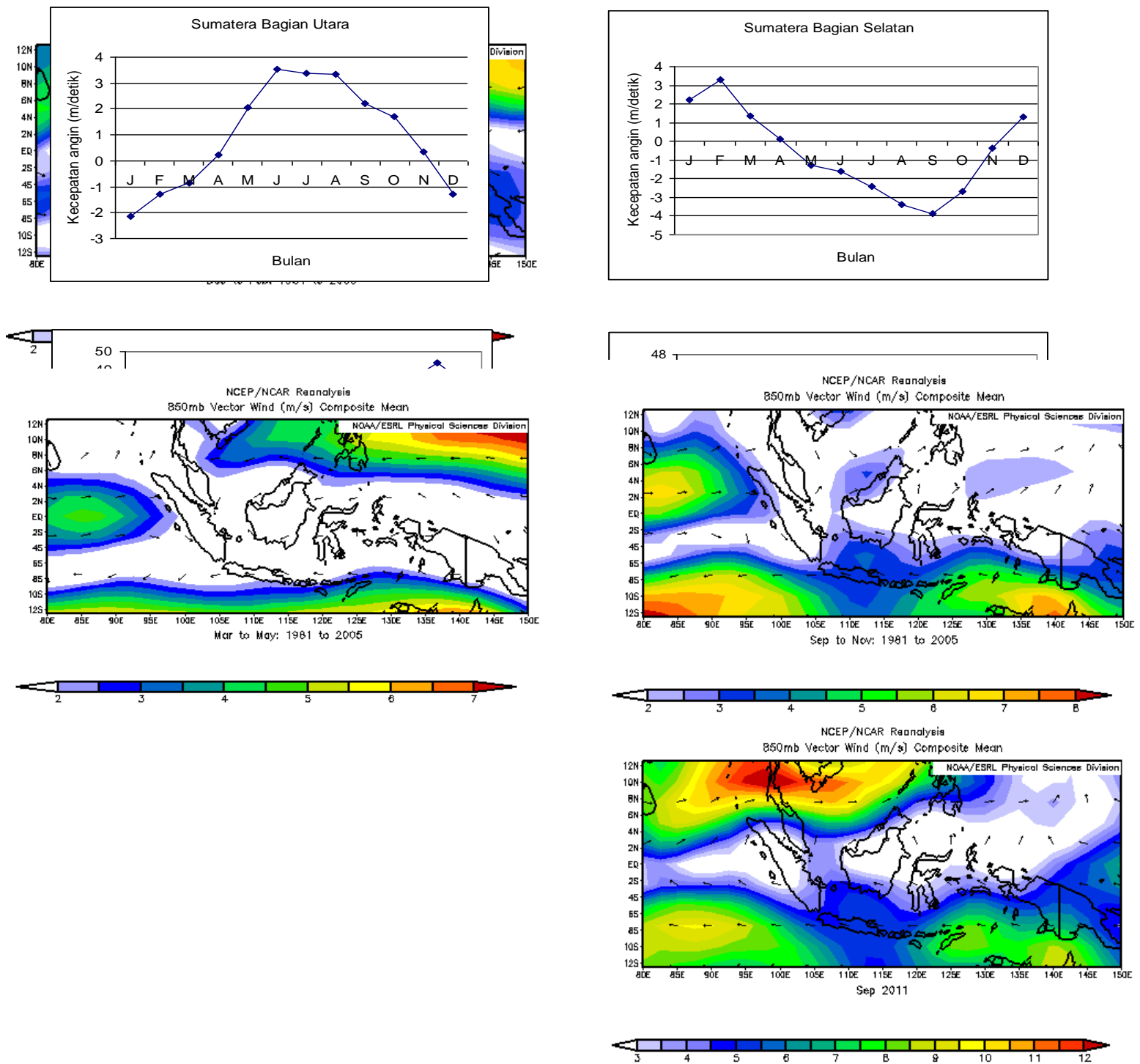
di Sumatra dan Semenanjung Malaysia hanya terjadi pada tahun 1998. Sebaliknya pada saat fase dingin di Nino 3 (1985, 1989, 1999, 2000) kondisi basah hanya terjadi pada tahun 1999 dan 2000). Pengaruh yang tidak konsisten ini disebabkan oleh anomali sirkulasi Walker yaitu terjadi konvergensi di pasifik Barat (bujur $105^{\circ} \mathrm{BT}$ ) dan Samudera Hindia. Kondisi ini diikuti oleh terbentuknya sirkulasi siklonik (cylonic circulation) di sekitar Philipina sampai Laut Cina Selatan. Kondisi anomali ini berbeda dengan pola Figure 1

Figure 2

angin normal. Prabowo (2011) juga menjelaskan pengaruh ENSO yang tidak
(Timuran-Baratan), JJA (Timuran), SON (Timuran) (Gambar 3 panel atas sebelah kanan).

Angin U850 dapat menangkap pola monsun dengan baik di Sumatera bagian selatan di banding bagian utara. Dari kondisi ini ini menunjukkan variabel angin dapat menangkap dengan baik karakteristik pada pola curah hujan tahunan. Sementara itu untuk pulau Sumatera pola angin di bagian selatan Sumatera (Gambar 4 panel atas bagian kanan)

sesuai dengan pola ketersediaan uap air (Gambar 4 panel bawah bagian kanan).

Gambar 4. Rata-rata kecepatan angin U850 mb dan Kadar uap air $\left(\mathrm{kg} / \mathrm{m}^{3}\right.$ di Sumatera bagian utara dan Selatan

Berdasarkan hubungan antara fenomena ENSO dengan curah hujan di wilayah Sumatra, maka dipilih kotak grid dengan lokasi $\left(80^{\circ} \mathrm{BT}-150^{\circ} \mathrm{BT}, 12,5^{\circ} \mathrm{LU}^{\circ}-12,5^{\circ}\right.$ LS). Kotak grid yang dipilih dalam bentuk peta seperti pada Gambar 2.

\section{HASIL DAN PEMBAHASAN}

\subsection{Monsun dan Curah hujan di Sumatra}

Untuk mendapatkan keterkaitan angin zonal U850 dapat menangkap pola monsun maka diakukan analisis rata-rata pola normal kecepatan angin rata-rata spasial observasi (1981-2005) di Sumatera bagian utara $\left(7,5^{\circ}\right.$ LU - -2,5 LS) dan Sumatera bagian selatan $\left(-2,5^{\circ} \mathrm{LU}--7,5^{\circ} \mathrm{LS}\right)$ pada $95^{\circ} \mathrm{BT}-17.5^{\circ} \mathrm{BT}$.

Wilayah Sumatera bagian utara pada umumnya angin baratan lebih dominan sepanjang bulan. Pada bulan Desember, Januari, Februari (DJF) menunjukkan angin Timuran, pada bulan Maret, April, Mei (MAM) menunjukkan angin TimuranBaratan), bulan Juni, Juli, Agustus (JJA) menunjukkan angin Baratan begitu juga September, Oktober, Nopember SON) (Gambar 3 panel atas sebelah kanan). Di Sumatera bagian selatan DJF (baratan), MAM

\section{Pola Angin dengan ENSO di Sumatera}

Korelasi angin zonal di wilayah Sumatera dan sekitar dengan nilai index Nino 3.4 tinggi > 0,6 dengan hubungan terbalik, ketika Nino 3.4 tinggi angin zonal rendah (angin melemah). Pada saat suhu muka laut di bagian tengah pasifik (Nino.3.4) meningkat (naik) maka kecepatan angin zonal di wilayah Sumatera mengalami penurunan (sirkulasi walker ke wilayah benua maritim Indonesia melemah). Sebaliknya pada saat suhu muka laut di Pasifik tengah mendingin (turun) sehingga pola silkulasi walker menguat (angin zonal dengan arah ke benua maritim naik) seperti pada Gambar 5.

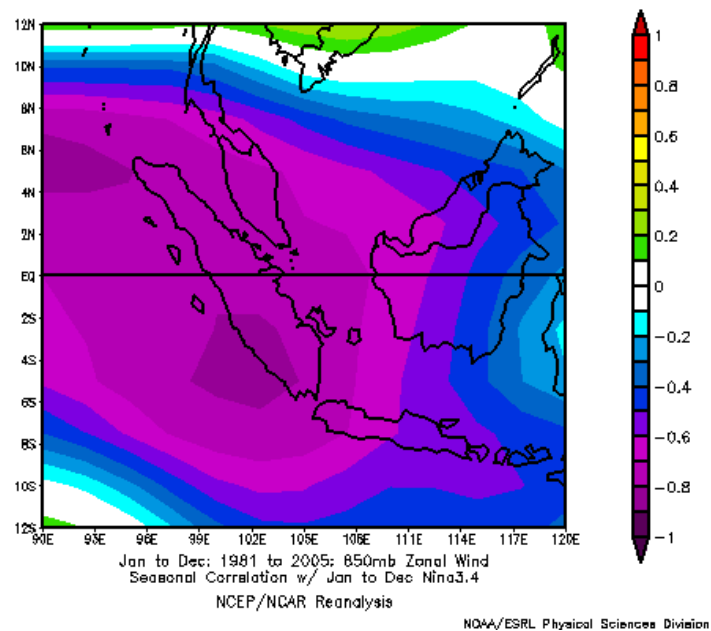


Gambar 5. Korelasi angin zonal dengan index Nino 3.4 pada periode tahun 1981-2005

Sementara itu untuk korelasi korelasi angin zonal dengan indeks SOI juga menunjukkan pola yang sama dengan korelasi angin zonal dengan Index Nino 3.4. Pada saat anan udara di wilayah Sumatra tinggi kecepatan angin yang zonal melemah, sebaliknya tekanan udara di wilayah Sumatera mengalami penurunan (warma oranye) saat angin zonal menguat ke arah baratan (sirkulasi walker) seperti pada Gambar 6.

Hasil korelasi antara angin zonal dan suhu muka laut komponen utama di wilayah Pasifik Barat menunjukkan pola yang sama dengan index nino 3.4, tekanan udara, dan suhu muka laut. Hasil korelasi menunjukan pada saat suhu muka laut di wilayah Pasifik tengah naik (suhu memanas) maka angin zonal mengalami penurunan kecepatan (angin timuran melemah). Pada saat suhu muka laut di pasifik tengah mengalami penurunan (suhu mendingin) kecepatan angin timuran menguat. Pola hubungan antara kedua variabel tersebut pada dilihat pada Gambar 6.

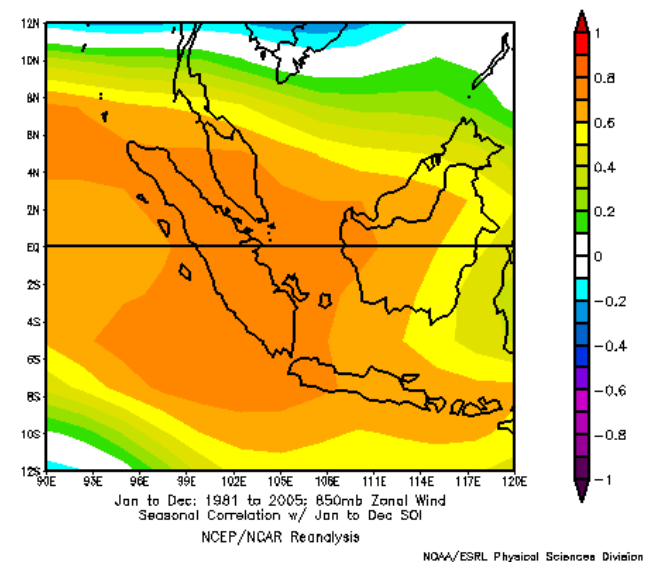

Gambar 6. Korelasi tekanan udara dan angin zonal spasial di wilayah Sumatera dan sekitarnya

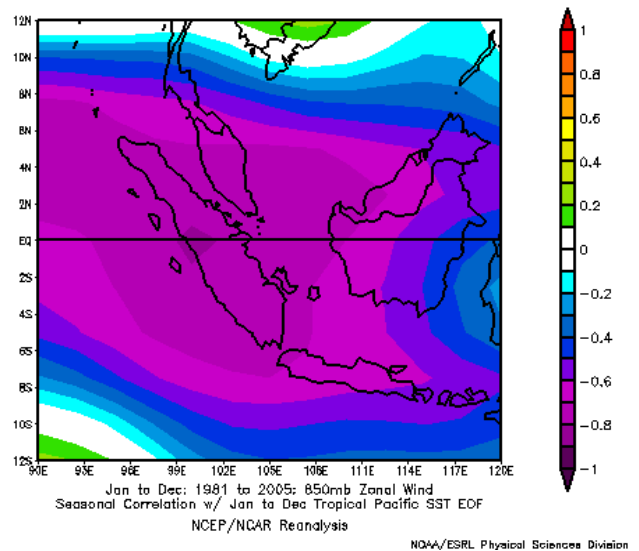

Gambar 6. Zonal wind dengan suhu muka laut Komponen utama Suhu permukaan laut

Dari pola index Nino 3.4, tekanan udara, dan suhu muka laut di pasifik menunjukkan hubngan yang kuat dengan angin zonal. Namun untuk wilayah Sumatera hubungan itu tidak semua linier dengan kondisi uap air yang terjadi. Rtinya tidak semua dipengaruhi oleh karakteristik angin zonal (ada pengaruh lokal). Karakteristik kondisi uap air menunjukkan bagian barat Sumatera tidak dipengaruhi secara kuat oleh pola global angin zonal. Hal ini dapat dilihat pada Gambar 7.

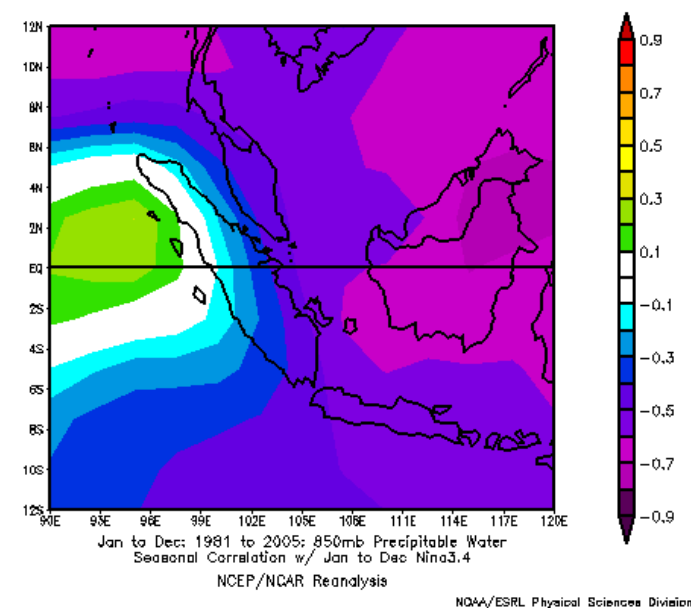

Gambar 7. Korelasi angin zonal dan air mampu curah (precipitable water) di Sumatra dan sekitarnya

\subsection{Kekuatan Hubungan antara Prediktor dan Curah Hujan}

Dari hasil analisis secara umum, nilai korelasi antara prediktor dan curah hujan pada kotak grid tersebut menunjukkan nilai di wilayah dengan siklus hujan tahunan lebih tinggi daripada di wilayah dengan siklus hujan 
tahunan. Untuk menjelaskan hal tersebut dianalisis berdasarkan homogenitas curah hujan. Berdasarkan homogenitas curah hujan, untuk Pulau Sumatra dibagi dalam dua daerah pola hujan (tahunan (A) dan semitahunan (B)) Aldrian dan Susanto (2003).

Hasil korelasi menunjukkan bahwa nilai yang lebih di wilayah Sumatera bagian Selatan (pola hujan A) lebih tinggi dari pada wilayah Sumatera bagian utara (pola hujan B). Untuk menjelaskan analisis ini digunakan wilayah pada kotak grid Benua maritim dan Sekitarnya yang mencakup lima wilayah (Laut Cina Selatan, Pasifik Barat, Teluk Benggala, dan Australia)

Nilai SCF (Square Covariance Factor) menunjukkan covariansi yang lebih kuat pada siklus hujan tahunan (Pola Hujan A) dari pada siklus hujan semitahunan pada mode kesatu maupun mode kedua (Tabel 2) Hal ini menunjukkan variabilitas curah hujan di wilayah siklus hujan semi tahunan (Pola Hujan B) lebih tinggi dari pada wilayah siklus hujan tahunan. Pada mode ke satu untuk pola hujan tahunan (A) faktor pola global (sirkulasi global) lebih kuat berpengaruh dari pada pola hujan semi tahunan (B). Hal ini ditunjukkan nilai kovariansi mode kedua yang lebih besar pada pola hujan B dari pada A. Kemampuan variabel prediktor lebih kuat menangkap pola variabilitas di pola hujan tahunan.

Tabel 2. Korelasi spasial variabel prediktor U850 dan curah hujan observasi pada wilayah Sumatra, pola hujan semi tahunan, dan pola hujan tahunan

\begin{tabular}{|c|c|c|c|c|c|}
\hline No & Daerah & $\begin{array}{c}\text { Mode } \\
1\end{array}$ & $\begin{array}{c}\text { Mode } \\
2\end{array}$ & SCF1 & SCF2 \\
\hline 1 & Sumatera & 0,77 & 0,63 & 92 & 7 \\
\hline
\end{tabular}

\begin{tabular}{|c|l|c|c|c|c|}
\hline 2 & $\begin{array}{l}\text { Semi } \\
\text { tahunan }\end{array}$ & 0,5 & 0,44 & 74 & 24 \\
\hline 3 & Tahunan & 0,77 & 0,48 & 99 & 1 \\
\hline
\end{tabular}

\subsection{Kemampuan Variabel Pediktor menangkap Pola Musiman dan Non Musiman secara Temporal}

Untuk mendapatkan kemampuan variabel predictor dalam menangkap pola curah hunan observasi diperoleh dari analisis daya wavelet. Poladeret waktu curah hujan observasi dibandingkan dengan deret waktu kemampuan variabel prediktor. Untuk mengetahui pola dominan curah hujan digunakan koefisien time series U850 pada mode ke-1 (Gambar 8) panel atas). Pola grafik deret waktu koefisien ekspansi variabel prediktor U850 dan curah hujan observasi menunjukkan fase yang mirip. Variabilitas curah hujan cukup tinggi terjadi pada tahun 1994 dan 1997 tidak dapat ditangkap dengan baik oleh mode kesatu variabel prediktor. Oleh karena itu mode yang kedua perlu dianalisis untuk mendapatkan anomali kejadian curah hujan observasi. Grafik menunjukkan pola variabilitas curah hujan kurang dapat ditangkap dengan baik pada pola kedua (Gambar 8 panel bawah). Pada pola anomali yang kedua pada secara umum variabel prediktor U850 dapat menangkap variasi pola curah hujan observasi

Untuk mengetahui kemampuan variabel prediktor dalam menangkap pola temporal (menurut waktu) dilakukan langkah lebih lanjut dengan analisis spektral menggunakan transformasi wavelet. Analisis ini dilakukan untuk mengetahui kemampuan variabel prediktor dalam menangkap pola osilasi Monsun, ENSO dan IOD secara temporal.

A. Koefisien Ekspansi variabel U850 Mode kesatu

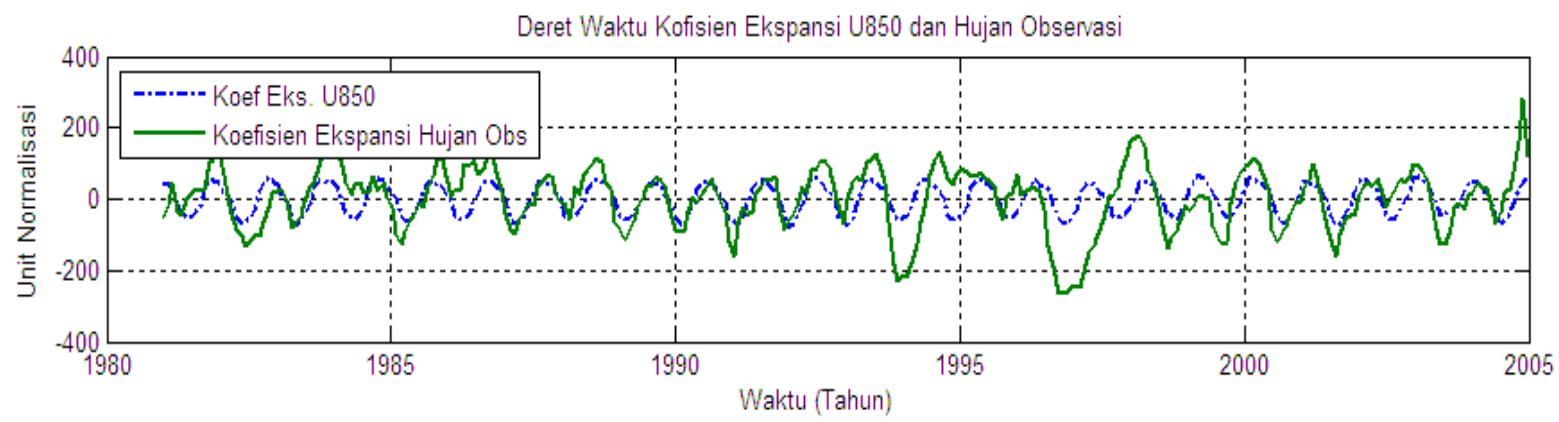


Dari analisis spektral terhadap indeks ENSO didapatkan osilasi terkuat 4 tahunan disusul dengan beberapa muncul dengan daya lebih kecil pada 3, 2 dan 12 tahunan (Gambar 9 ).

Berdasarkan kondisi ini maka terlihat bahwa pola osilasi tahunan ENSO adalah 4 tahunan disusul 2, 8, 12 tahunan. Variabel prediktor perlu kemampuan untuk menangkap pola musiman (Monsun) dan non musiman (ENSO-IOD).

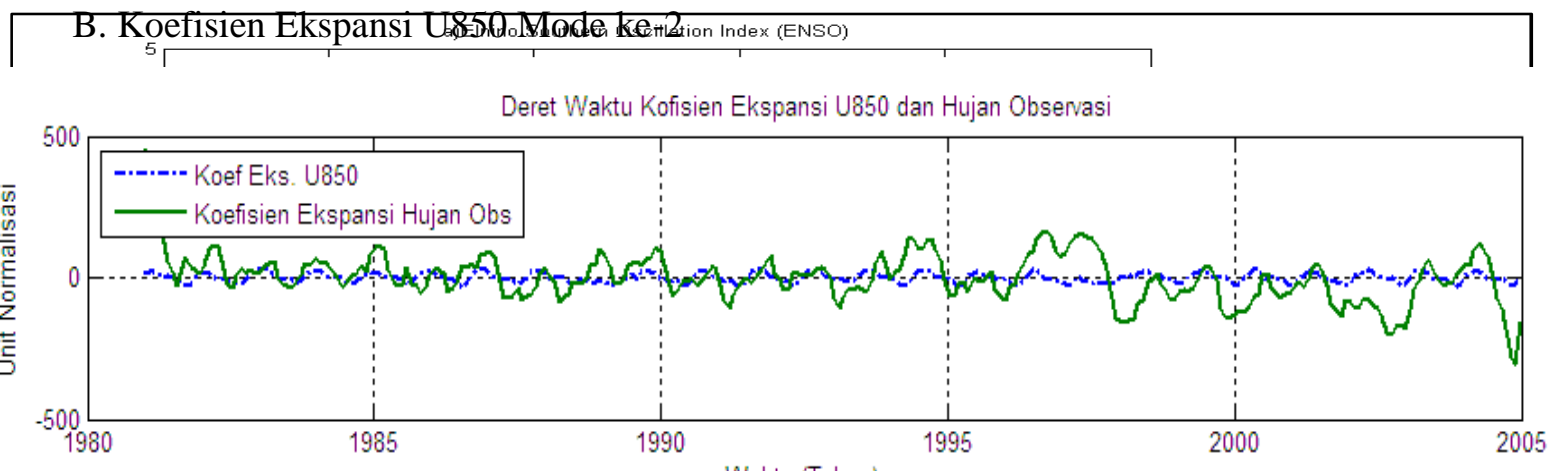

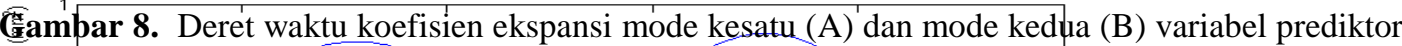

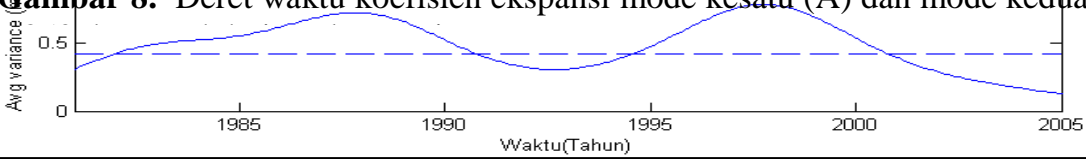

Gambar 9. Spektrum daya wavelet variabel angin zonal (U850) index ENSO. Sumber data : http://www.cpc.ncep.noaa.gov/products/analysis_monitoring/ensostuff/ensoyears.shtml

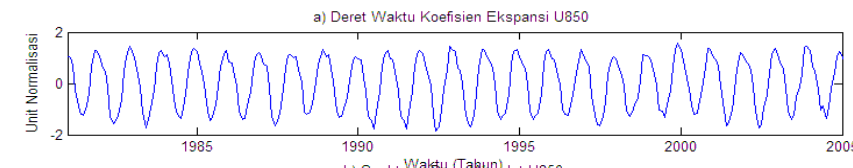

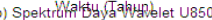

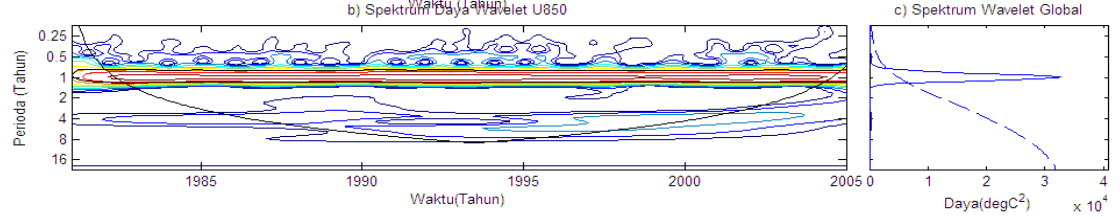



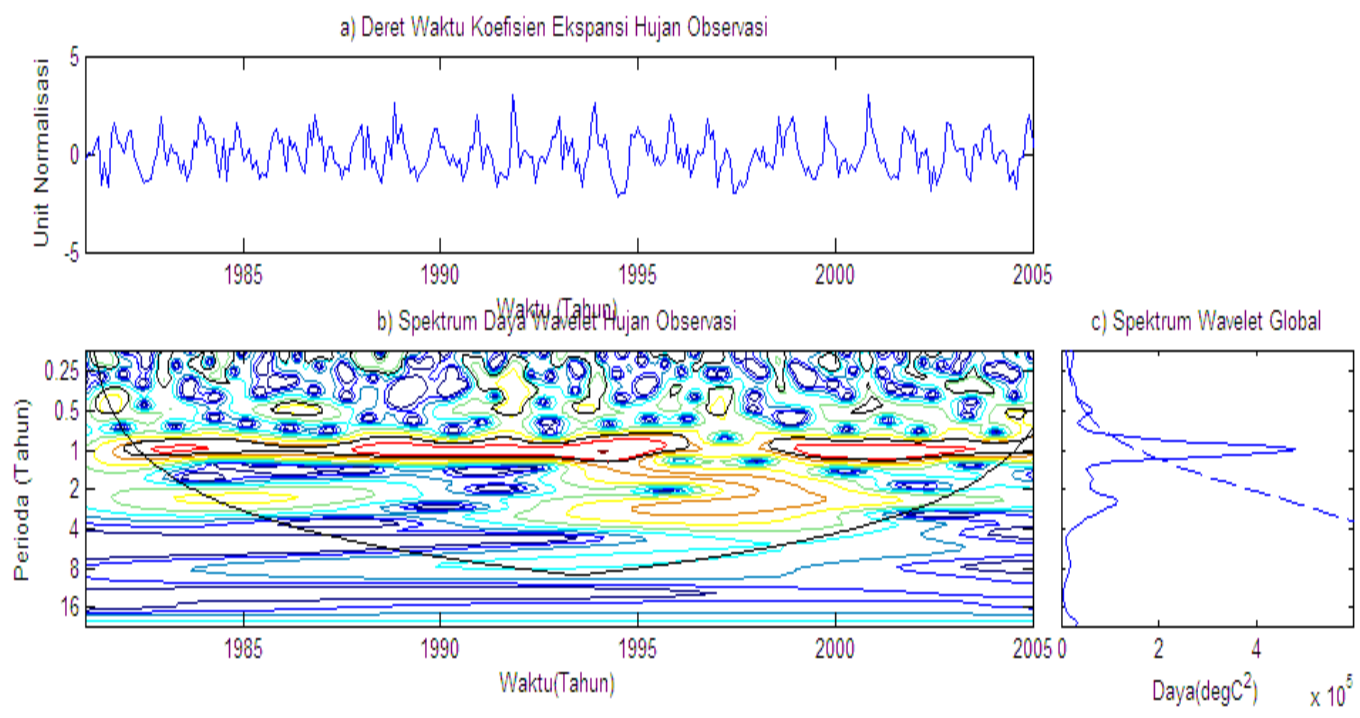

Gambar 10. Spektrum daya wavelet a. variabel angin zonal (U850) dan b. curah hujan observasi mode kesatu

Hasil analisis spektral menunjukkan pola tahunan dapat ditangkap dengan baik oleh variabel prediktor pada koefisien ekspansi dominan ke-1 (Gambar 3.12 panel atas). Sedangkan osilasi ENSO dan IOD belum dapat ditangkap pada pola hujan seperti pola hujan observasi (Gambar 10 panel bawah). Pada pola hujan observasi muncul pola osilasi 2 dan 0.5 tahunanUntuk mendapatkan pola yang belum ditangkap pada pola dominan kesatu digunakan pola dominan kedua (Gambar 11).
Pada pola dominan yang kedua (mode kedua) menunjukkan pola satu tahunan paling dominan pada U850 dapat menangkap dengan baik pola satu tahunan curah hujan observasi. Selain pola satu tahunan koefisien ekspansi variabel U850 ke 2 juga dapat menangkap pola osilasi dominan 4, 12, 2, dan 0,5 tahunan seperti yang ditangkap oleh curah hujan observasi. Dengan kondisi ini dapat disimpulkan bahwa variabel prediktor angin dapat menangkap musiman (Monsun) dan pola non musiman (ENSO-IOD).
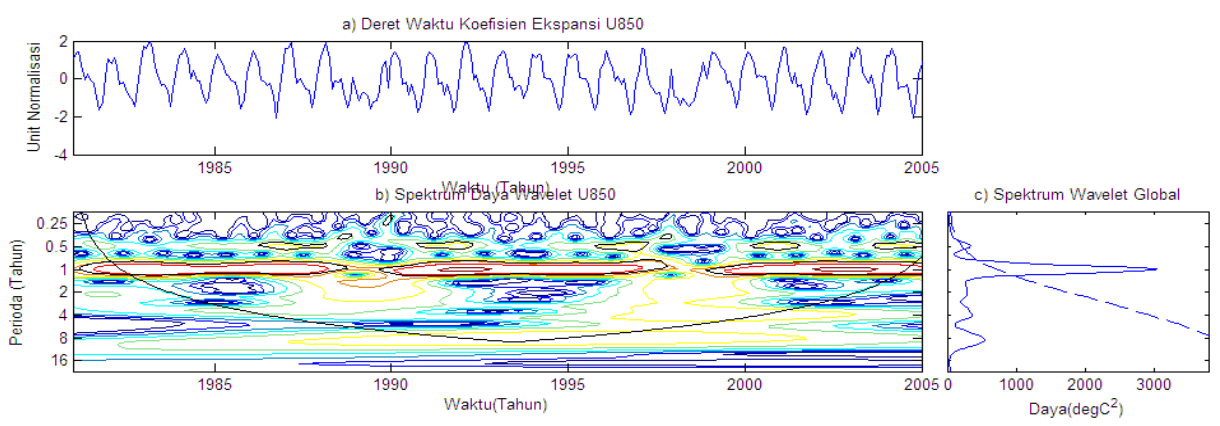

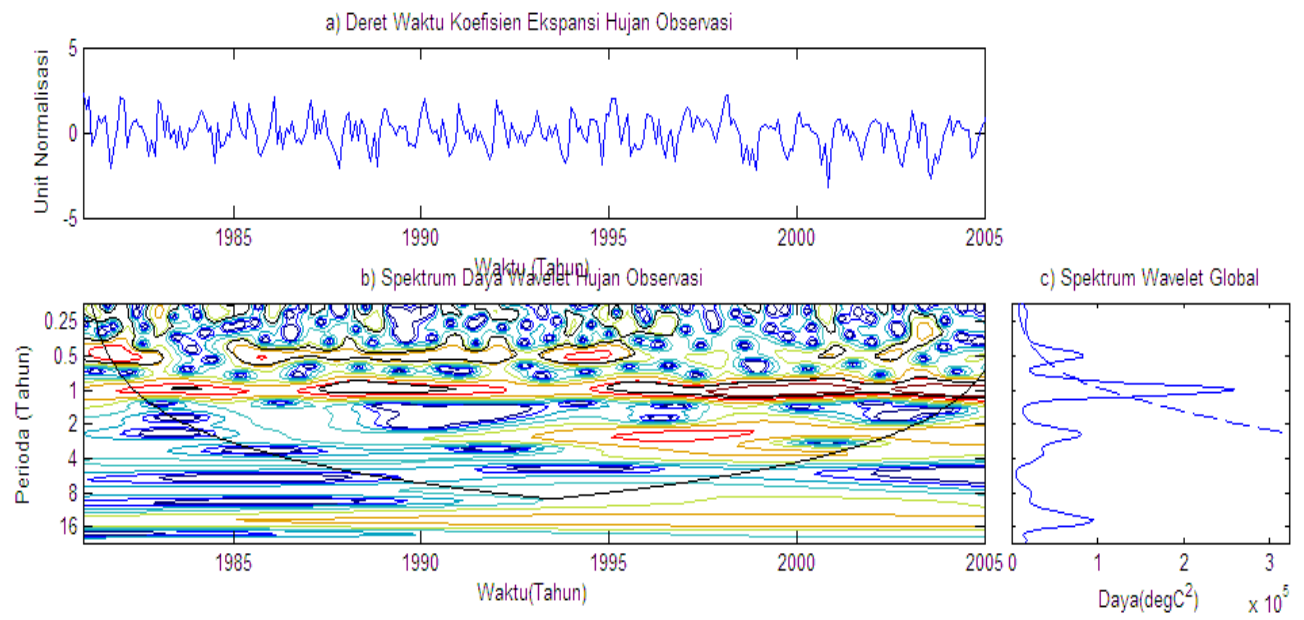

Gambar 11. Spektrum daya wavelet a. variabel angin zonal (U850) dan b. curah hujan observasi mode kedua 
Untuk mempermudah análisis pola osilasi dominan disajikan dalam bentuk Tabel (Tabel 3). Pola osilasi yang dapat ditangkap variabel prediktor U850 terhadap curah hujan observasi pola musiman dan semi musiman $(1,0,5)$ tahunan dan non musiman $(2,4,12)$ tahunan.

Tabel 3. Perbandingan osilasi U850 dan curah hujan observasi

\begin{tabular}{|c|c|c|}
\hline No & \multicolumn{2}{|c|}{ Perioda (tahun) } \\
\hline $\begin{array}{c}\text { Koefisien } \\
\text { ekspansi }\end{array}$ & U850 & $\begin{array}{c}\text { Hujan } \\
\text { Observasi }\end{array}$ \\
\hline $\begin{array}{c}\text { Mode (1) } \\
(93 \%)\end{array}$ & 1 & 1,2 \\
\hline $\begin{array}{c}\text { Mode (2) } \\
(7 \%)\end{array}$ & $\begin{array}{c}1,2,4,12, \\
(0,5)\end{array}$ & $\begin{array}{c}1,2,4,12, \\
(0,5)\end{array}$ \\
\hline
\end{tabular}

\subsection{Pengaruh Fenomena Lokal terhadap Curah Hujan di Pantai Barat Sumatera}

Korelasi rendah di pantai barat kibat faktor geografi yang mempengaruhi distribusi uap air adalah sirkulasi lokal yang disebabkan oleh faktor pegunungan. Variabilitas curah hujan skala lokal ketika monsun berinteraksi dengan topografi. Efek lokal ini dominan pada saat sirkulasi monsun melemah yang terjadi pada musim intermonsun/pancaroba (MAM dan SON). Dalam kondisi angin monsun dominan sirkulasi lokal mengalami konvergensi dengan angin monsun. Sebagai contoh untuk Sumatra, angin yang membawa uap air pada skala regional akan menumpuk ketika terhalang pegunungan tinggi (2000-3000 meter). Oleh karena itu curah hujan yang lebih tinggi di sisi barat Sumatra yang terdiri dari pegunungan tinggi Bukit Barisan dibanding timur Sumatra yang terdiri dari dataran rendah (Prabowo, 2011).

Uap air lokal ini menambah uap air yang sudah dibawa oleh monsun sehingga meningkatkan jumlah curah hujan. Uap air lokal ini diperoleh dari sirkulasi lokal darat-laut, sebagai contoh angin laut yang kuat membentuk awan pada sore (pukul 17.00 waktu setempat) di pegunungan Bukit Barisan Sumatra.

\section{KESIMPULAN DAN SARAN}

\subsection{Kesimpulan}

Variabel angin zonal (U850) dapat digunakan sebagai prediktor umum (tunggal) untuk prediksi hujan bulanan di Sumatera. Berdasarkan variasi terhadap waktu variabel U850 mampu menangkap variabilitas iklim tahunan (monsun) dan antar tahunan (0,5 tahunan) yang meliputi ENSO dan IOD (4, 12, 2, tahunan). Korelasi angin zonal di wilayah Sumatera dan sekitar dengan nilai index Nino 3.4 tinggi > 0,6 dengan hubungan terbalik, ketika Nino 3.4 tinggi angin zonal rendah (angin melemah). Indeks osilasi selatan (SOI) juga menunjukkan pola keterkaitan yang erat dengan angin zonal.

Variabel prediktor U850 layak digunakan di benua maritim karena dapat menangkap variabilitas iklim akibat monsun, ENSO, dan IOD. Hasil korelasi menunjukkan keterkaitan pola angin U850 terkait erat dengan curah hujan di Sumatera. Hal ini ditunjukkan dengan nilai korelasi $(0,77)$ dan kesamaan keragamaan pasangan data (kovariansi) $92 \%$.

Terdapat perbedaan kemampuan variabel prediktor U850 di wilayah dengan curah hujan berpola tahunan dan semitahunan. Kekuatan hubungan di pola hujan tahunan lebih tinggi (nilai korelasi 0,77 dan kovariansi $74 \%$ ) dari pada pola hujan semitahunan (nilai korelasi 0,5 kovariansi 0,77 )

Perbandingan spasial antara variabel U850 keluaran model GCM dan observasi secara menunjukkan bahwa variabel dapat menangkap siklus semi tahunan dan semitahunan dengan baik. Hal ini ditunjukkan dengan pola angin zonal dan distribusi uap mengikuti pola distribusi uap air di wilayah Sumatra baik pada periode DJF dan JJA.

Variabel U850 kurang menangkap dengan baik untuk karakteristik curah hujan di pantai Barat. Pola lokal yang muncul (harian) akibat angin darat dan laut di Pantai barat Sumatra 
menyebabkan variabel U850 tidak memiliki hubungan yang kuat dengan curah hujan di wilayah tersebut.

\subsection{Saran}

Dari hasil penelitian ini masih untuk wilayah Pantai Barat Sumatera tingkat kemampuan variabal prediktor untuk itu perlu penelitian varaibel prediktor lain untuk menangkap variabilitas curah hujan yang terjadi.

\section{DAFTAR PUSTAKA}

Aldrian, E. dan Susanto, R. D. 2003. Identification of Three Dominant Rainfall Regions within Indonesia and Their Relationship to Sea Surface temperature, International Journal of Climatology, 23, 1435-1452.

Ashok, K., Zhaoyong, Saji, N.H dan Yamagata, T. 2004. Individual and Combined Influences of ENSO and The Indian Ocean Dipole on The Indian Summer Monsoon, Journal of Climate, 17, 31413155 .

Bayong, T. H. K., Lubis A., Junaeni, I., Ruminta, dan Harijono, B. W. 2008. The impact of Temperature Variation from Pasicific Ocean and Equtorial for the Rainfall in Indonesia, Jurnal Sains Dirgantara, 5, 83-181.

Bjornson, H., dan Venegas S.A. 1997. A Manual for EOF and SVD Analysis of Climatic Data, Departement of Atmospheric and Oceanic Sciences and Centre for Climate and Global Change Research, Mc Gill University.

Boer, R., Wahab I., dan Hariadi H.M. 2007. Undetstanding Farmer's Need to Climate Information, Jurnal Meteorologi dan Geofisika, 8, 2.

Chang, C.P., Wang Z., Ju J., dan Li T. 2004. On the Relationship between Western Maritim Continent Monsoon Rainfall and
ENSO during Northern Winter, Journal of Climate, 17,665-672.

Chang, C.P., McBride J., dan Liu C. 2005. Annual Cycle of Southeast Asia-Maritim Continent Rainfall and the Asymmetric Monson Transition, Journal of Climate, 18, 287-301.

Harijono, S. B. 2008. Interaksi Fenomena El Niño dan Dipole Mode Secara Simultan serta Monsun Musim Panas India Terhadap Variabilitas Curah Hujan di Sumatra Bagian Utara, Disertasi, Institut Teknologi Bandung.

Hendon, H. H. 2003. Indonesian Rainfall Variability: Impacts of ENSO and Local Air-Sea Interaction, Journal of Climate, 16, 1775-1789.

Juneng, L., Tangang T. F., Kang H., Lee, Woo J., dan Seng Y.P. 2010. Statistical Downscaling Forecasts For Winter Monsoon Precipitation In Malaysia, Using Multimodel Output Variables, Journal of Climate, 23, 17-27.

Kang, K., An K.H, Park C.K., dan Solis L.S. 2007. Multimodel Output Statistical Downscaling Prediction of precipitation in the Philippines and Thailand, Geophysical Research Letts, 34.

Mason, J. S., dan Baddour O. 2008. Statistical Modeling, 163-200, dalam Troccoli (2008) : Seasonal Climate: Forecasting and Managing Risk

Nicholls, S.D. dan Young, S.G. 2007. Dendritic Patterns in Tropical Cumulus an Observational Analysis, Monthly Weather Review, 135, 1994-2001.

Prabowo, A. A. 2010. Kajian anomali Curah Hujan di Wilayah Sumatra bagian Utara, Tesis Magister, Institut Teknologi Bandung. 
Qian, J. 2008. Mostly Concentrated Over Islands in The Maritime Continent, Journal of The Atmospheric Sciences, 65.

Ratri, D. N., Boer R., dan Kusnomo T. 2007. Institution Mechanism In Extending Climate Forecast Information and Its Utilization (Case Study of Indramayu District), Buletin Meteorologi dan Geofisika, 3, 1.

Supari, S., Ettema J., dan Aldrian E. 2011. Spatio-temporal Characteristics of Extreme Rainfall Events over Java IslandIndonesia, Indonesian Journal of Geography., 44, $62-86$.

Tatli, H., Dalfes H., Nu“ Zhet, Mentes B., dan Sibel S. A. 2004. Statistical Downscaling Method For Monthly Total Precipitation Over Turkey, International Jurnal Of Climatolology, 24, 161-180.

Torrence, C. dan Compo, G.P. 1998. A Practical Guide to Wavelet Analysis, Bulletin of the American Meteorological Society.

Wilby, R.L., Charles S.P., Zorita E., Timbal B., Whetton P., dan Mearns. 2004. Guidelines for Use of Climate Scenarios Developed from Statistical Downscaling Methods, IPCC (Intergovernmental Panel of Climate Change, 2004).

Wu, P., Hamada, J.I, Mori, S., Tauhid, Y.I, dan Yamanaka, M.D. 2003. Diurnal Variation of Precipitable Water over a Mountainous Area of Sumatra Island, Journal of Applied Meteorology, 42, 1107-1115.

WMO (World Meteorological Organization). 2001. Commission for Basic Systems Expert Team Meeting on Infrastructure for Long-Range, Forecasting Geneva, Switzerland, 12-16 November 2001. 